\title{
Nanomedisin i kreftbehandling - håp til små partikler
}

\author{
Nanopartikler har vist å kunne forbedre farmakokinetikk, terapeutisk effekt og bivirkningsprofil av antineo- \\ plastiske legemidler. Foreløpig finnes det få nanomedisiner for kreftbehandling på markedet. Forskning \\ og utvikling av nanomedisiner vil forhåpentligvis resultere i bedre kreftbehandling.
}

Tove Julie Evjen

tove.julie@gmail.com

Konvensjonell kjemoterapi gir uspesifikk distribusjon av cellegift i kroppen, noe som gir systemiske bivirkninger, dosebegrensninger og redusert effekt. Vi trenger derfor en mer målrettet kreftbehandling. Behovet for spesifikk legemiddelbehandling har ført til økt innsats for å utvikle målrettede medisiner ved hjelp av nanoteknologi. Globalt investeres milliarder av kroner årlig til utvikling av nanomedisiner, og det er store forventninger til hvilken rolle nanomedisin vil spille i kreftbehandlingen de nærmeste årene. Nanopartikler har vist seg å kunne forbedre egenskaper til kreftmedisiner og målstyre legemidlene til kreftceller. Flere typer nanopartikler er under utvikling og noen få har nådd klinisk bruk.

\section{Transport og målstyring av legemidler}

Nanopartikler har en størrelse i nanometerskala (typisk 10-200 nm i diameter) og kan konstrueres til å bære legemiddelmolekyler eller diagnostiske markører. Legemiddelmolekyler kan dessuten moduleres til en størrelse i nanometerskalaen, for eksempel ved konjugering til polymerer. I denne artikkelen brukes begrepet nanomedisin om nanopartikler som legemiddelbærere. Ved å inkorporere et legemiddel i en nanopartikkel kan egenskapene til legemidlet forbedres, som for eksempel økt stabilitet, redusert eliminasjon fra blod og styring til kreftceller. For å oppnå slike forbedringer må partikkelen være ikke-toksisk, kompatibel med virkestoffet og stabil ved lagring og i blodbanen (1).

En ønsket virkning av nanopartikler i kreftbehandling er å målstyre legemidler til kreftceller. Partiklene akkumuleres på virkestedet der virkestoffet leveres. Dette vil kunne gi færre bivirkninger og forbedre den terapeutiske effekten (2).

Målstyring av nanopartikler til virkested kan skje passivt og aktivt og baserer seg på ulikheter mellom friske celler og kreft- celler. På grunn av unormal rask celledeling har tumorer behov for økt blodtilførsel, og endotelcellemembranen i omkringliggende blodårer vil ofte være defekt. Dette gjør at nanopartikler passivt kan slippe gjennom blodårene og inn i tumorvevet. Videre fører redusert lymfatisk drenasje i tumor til at partiklene holdes tilbake og akkumuleres over tid (3). Det er vist at nanopartikler kan akkumulere 10-50 ganger mer i tumor sammenliknet med friskt vev (4), og ti ganger mer enn samme dose av fritt legemiddel (5).

En strategi for ytterligere å øke spesifisiteten av nanopartiklene til tumorceller er å tilsette tumorspesifikke ligander til partikkelens overflate, som f.eks antistoffer. Via spesifikke reseptorer som er overrepresentert på tumorcellen, vil antistoffet festes til tumorcellen slik at partikkelen med legemidlet tas opp aktivt (6).

Generelt vil nanopartikler som injiseres i blodbanen raskt bli tatt opp av immunsystemet og eliminert. Det var derfor et stort fremskritt da forskere oppdaget at ved å omslutte partiklenes overflate med polymerer som polyetylenglykol (PEG), såkalt pegylering, ble sirkuleringstiden i blod vesentlig forlenget slik at partiklene kunne akkumulere i tumorer (7). Hovedteorien går ut på at polyetylenglykol danner en sterisk barriere mot opsoniner (proteiner) i blod slik at opptak av partiklene i det mononukleære fagocyttsystemet reduseres (8).

\section{Klinisk anvendelse}

Nanopartikler har allerede fått en viktig plass i kreftterapi. Tabell 1 viser ulike nanomedisiner som har nådd markedet. Generelt kan man si at de markedsførte nanomedisinene hovedsakelig drar nytte av en forbedret farmakokinetikk og/eller bivirkningsprofil sammenliknet med virkestoffet alene. Forskere håper imidlertid på at flere av produktkandidatene som gjennomgår prekliniske og kliniske studier også vil vise en økt antitumoreffekt via forbedret målstyring mot kreftceller. De mest studerte og biokompatible nanopartiklene er liposomer, miceller, polymerer og proteiner (fig 1).

Liposomet er den første og mest studerte nanopartikkelen, oppdaget av Alec Bangham i 1960-årene. Liposomet består av fosfolipidlag rundt en vandig kjerne og kan inkorporere både vandige og fettløselige virkestoffer. Det ble tidlig knyttet skyhøye forventninger til liposomets potensial i kreftbehandling. Liposomet ble omtalt som «the magic bullet that would cure cancer». Selv om dette har vist seg å være en overdrivelse, finnes det $\mathrm{i}$ dag flere liposomale formuleringer på markedet for kreftbehandling (tab 1). Pegylert liposomal doksorubicin var den første nanoformuleringen som ble markedsført. Produktet brukes for behandling av aidsrelatert Kaposis sarkom, tilbakevendende ovariekreft og metastaserende brystkreft, og selger for over 600 millioner dollar årlig (9). I tumorbærende forsøksdyr viste formuleringen en betydelig forbedret terapeutisk effekt sammenliknet med doksorubicin alene (9), men denne forbedringen ble ikke observert i klinisk utprøvning. Produktet nådde imidlertid markedet pga. en gunstig farmakokinetikk og en forbedret bivirkningsprofil, hovedsakelig med hensyn til kardiotoksisitet (9).

Det er andre liposomale preparater på markedet (tab 1). Disse preparatene er ikke pegylerte og vil derfor ha kortere sirkulasjonstid i blod. Flere liposomale kjemoterapeutika er under klinisk utprøvning (10).

Polymere miceller består av overflateaktive stoffer (polymerer) som over en viss konsentrasjon danner en sfære bestående av en hydrofob kjerne og et hydrert skall. Fettløselige legemidler kan inkluderes i kjernen og vannløselige legemidler i skallet. Miceller har vist seg gunstige som oppløsningsfremmere av lipofile virkestoffer (11). Ved å unngå bruk av toksiske løsemidler som tradisjonelt sett har vært benyttet i formulering av lipofile virkestoffer, vil maksimal tolerert dose av legemidlet økes, og dermed også dose-respons-sammenhengen. En micellær formulering av paklitaksel er markedsført i Korea mot bryst- og lungekreft og utprøves i kliniske studier i USA mot kreft i bukspyttkjertelen (12).

Nanopartikler kan lages av ulike typer polymerer som f.eks. kitosan, polyglykosider og cellulosederivater. Legemidlet kan 

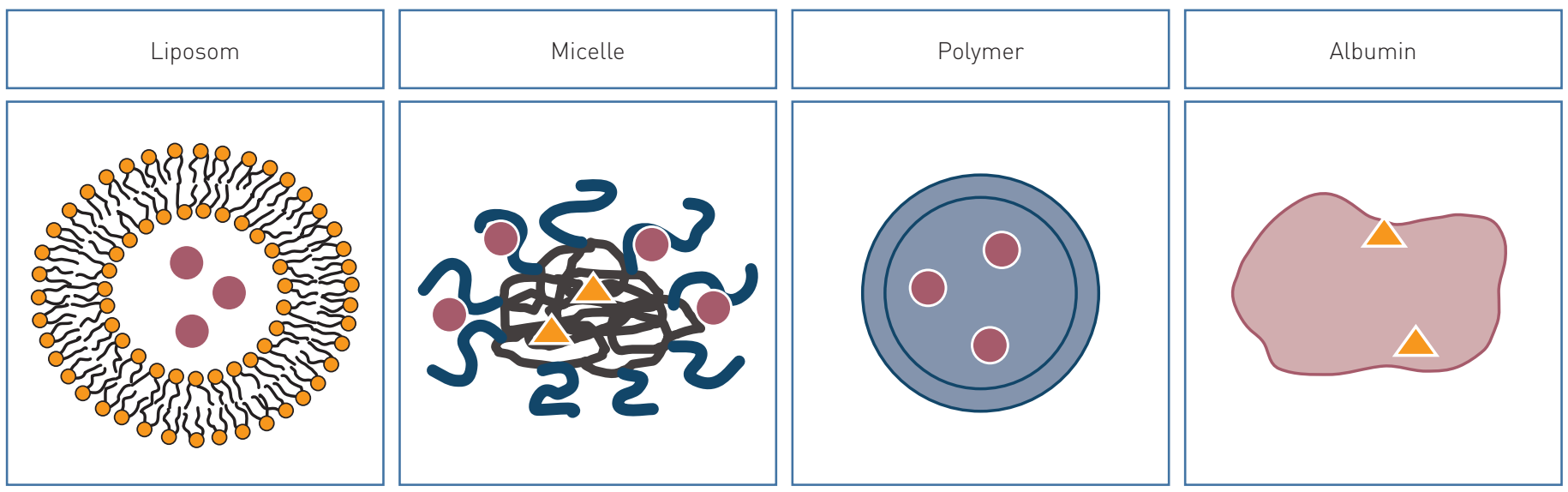

ॠosfolipid

Hydrofilt/amfifilt legemiddel

$\Delta$ Lipofilt legemiddel

20 Polymerer

Lipofilt segment

Figur 1 Illustrasjon av ulike nanopartikler i kreftterapi

løses, assosieres eller innkapsles i nanopartikkelen avhengig av produksjonsmåten. I de siste årene har polymerer vist seg å være egnet for målstyring av peptider, antistoffer og genmateriale (13). I tillegg til målstyring, beskytter polymerene disse substansene mot enzymatisk degradering etter intravenøs injeksjon (14). Flere typer polymere nanopartikler gjennomgår per dags dato kliniske studier (15).

Albumin er kroppens egen transportør av lipider. Albumin har også evnen til å transportere lipofile legemidler i blodbanen. En albuminbasert formulering som inneholder paklitaksel finnes på markedet. Ved å formulere paklitaksel med albumin, unngår man å bruke toksiske løsemidler. I tillegg bindes albumin til proteinet gp60 som er overuttrykt på visse typer tumorer, og man oppnår således målstyring av albuminbundet paklitaksel (16). Produktet er i bruk mot metastaserende brystkreft og er under utprøvning for behandling av ulike typer solide tumorer (16).

\section{Veien frem til klinisk bruk}

Antall publikasjoner om nanomedisiner i kreftbehandling har økt kraftig de siste årene. I 2011 var det globale nanomedisinmarkedet generelt verdt 50 billioner dollar og er beregnet til å vokse med $14 \%$ årlig frem til 2016 (17). Med den store satsingen og mange gode prekliniske og kliniske studier, skulle man kanskje forventet flere nanomedisiner til bruk i kreftbehandling.

Mange kliniske studier har vist seg ikke å bekrefte data fra prekliniske studier.

Årsaker til dette kan være store variasjoner i forsøksdesign for prekliniske studier. Ulike cellelinjer, tumorstørrelser, administrering og dosering av legemiddel gjør det vanskelig å gjennomføre metaanalyser. I tillegg vil ulikheter i tumorfysiologi mellom dyremodeller og menneske ofte føre til svært ulik målstyring og akkumulering av nanomedisin i tumor. Mer standardiserte prekliniske forsøksdesign

vil kunne gjøre det lettere å sammenlikne data og dermed gi et bedre utgangspunkt

Tabell 1 Markedsførte antineoplastiske nanomedisiner

\begin{tabular}{|c|c|c|c|}
\hline Legemiddel & Nanobærer & Virkestoff & Hovedindikasjon \\
\hline Caelyx & Pegylert liposom & Doksorubicin & $\begin{array}{l}\text { Metastaserende brystkreft } \\
\text { Fremskreden ovariekreft } \\
\text { Avansert aidsrelatert Kaposis sarkom }\end{array}$ \\
\hline Myocet & Liposom & Doksorubicin & Metastaserende brystkreft \\
\hline DaunoXome & Liposom & Daunorubicin & Avansert aidsrelatert Kaposis sarkom \\
\hline Abraxane & Albumin & Paklitaksel & Metastaserende brystkreft \\
\hline DepoCyte & Liposom & Cytarabin & Lymfomatøs meningitt \\
\hline Marqibo & Liposom & Vinkristin & Akutt lymfoblastisk leukemi \\
\hline
\end{tabular}

for å vurdere testing av produktkandidater i kliniske studier.

En annen utfordring for produktutvikling og markedsføring av nanomedisin er økonomiske og regulatoriske barrierer. Det er utvilsomt mer ressurskrevende å bringe nanomedisin til markedet enn konvensjonelle molekyler. Før godkjenning må alle komponentene i nanopartikkelen evalueres på lik linje med virkestoffet alene og $\mathrm{i}$ kombinasjon med nanopartikkelen. For nye patenterte virkestoff, som f.eks. monoklonale antistoffer, vil dette bety at legemiddelselskapene ofte heller søker godkjenning av virkestoffet alene enn å formulere det som en nanomedisin. Konsekvensen kan bli at pasienten går glipp av en bedre medisin. Regulatoriske myndigheter som U.S. Food and Drug Administration jobber imidlertid med å generalisere regulatoriske krav til kjente typer nanopartikler slik at det skal bli lettere å søke markedsføringstillatelse.

Til tross for teknologiske, økonomiske og regulatoriske utfordringer har nanomedisin allerede vist sin nytte i kreftterapi. Flere lovende produkter er underveis i kliniske studier. Forhåpentligvis vil videre forskning på nanomedisin kunne resultere i utvikling av nye målrettede terapier innen kreft.

\section{Tove Julie Evjen (f. 1982)}

er farmasøyt (cand.pharm.), ph.d. i legemiddelteknologi og er forsker i Aker Biomarine Antarctic. Hun har tidligere erfaring fra sykehusapotek og kreftforskning fra bioteknologiselskap og Universitetet i Troms $\varnothing$.

Forfatter har fylt ut ICMJE-skjemaet og oppgir ingen interessekonflikter. 


\section{Litteratur}

1. Peer D, Karp JM, Hong S et al. Nanocarriers as an emerging platform for cancer therapy. Nat Nanotechnol 2007; 2: 751-60.

2. Estanqueiro M, Amaral MH, Conceição J et al. Nanotechnological carriers for cancer chemotherapy: the state of the art. Colloids Surf B Biointerfaces 2015; 126: 631-48.

3. Jain RK. Delivery of molecular medicine to solid tumors. Science 1996; 271: 1079-80.

4. Iyer AK, Khaled G, Fang J et al. Exploiting the enhanced permeability and retention effect for tumor targeting. Drug Discov Today 2006; 11 : 812-8.

5. Allen TM, Cullis PR. Drug delivery systems: entering the mainstream. Science 2004; 303: 1818-22.

6. Lammers T, Kiessling F. Hennink WE et al. Drug targeting to tumors: principles, pitfalls and (pre-) clinical progress. J Control Release 2012; 161 175-87

7. Gabizon A, Catane R, Uziely B et al. Prolonged circulation time and enhanced accumulation in malignant exudates of doxorubicin encapsulated in polyethylene-glycol coated liposomes. Cancer Res 1994: 54: 987-92.

8. Harris JM, Chess RB. Effect of pegylation on pharmaceuticals. Nat Rev Drug Discov 2003; 2: 214-21.

9. Barenholz Y. Doxil $@-t h e$ first FDA-approved nanodrug: lessons learned. J Control Release 2012; 160: 117-34.

10. Wang R, Billone PS, Mullet W. Nanomedicine in action: An overview of cancer nanomedicine on the market and in clinical trials. J Nanomater 2013; 2013: 1-12.

11. Torchilin VP. Structure and design of polymeric surfactant-based drug delivery systems. J Control Release 2001; 73: 137-72

12. Lee JL, Ahn JH, Park SH et al. Phase II study of a cremophor-free, polymeric micelle formulation of paclitaxel for patients with advanced urothelial cancer previously treated with gemcitabine and platinum. Invest New Drugs 2012; 30: 1984-90.

13. Shi Y, Huang G. Recent developments of biodegradable and biocompatible materials based micro/ nanoparticles for delivering macromolecular therapeutics. Crit Rev Ther Drug Carrier Syst 2009; 26: $29-84$.

14. Lares MR, Rossi JJ, Ouellet DL. RNAi and small interfering RNAs in human disease therapeutic applications. Trends Biotechnol 2010; 28: 570-9.

15. Prabhu RH, Patravale VB, Joshi MD. Polymeric nanoparticles for targeted treatment in oncology: current insights. Int J Nanomedicine 2015; 10: $1001-18$.

16. Seigneuric R, Markey L, Nuyten DS et al. From nanotechnology to nanomedicine: applications to cancer research. Curr Mol Med 2010; 10: 640-52.

17. Markets OTC. www.otcmarkets.com (3.8.2015).

Mottatt 30.10. 2014, første revisjon innsendt 31.3. 2015, godkjent 3.8. 2015. Redaktør: Trine B. Haugen. 